Article

\title{
New and Emerging Challenges to Heritage and Well-Being: A Critical Review
}

\author{
Paul S.C. Taçon ${ }^{+, *(1)}$ and Sarah Baker ${ }^{+}$(i) \\ Griffith Centre for Social and Cultural Research, Griffith University, Gold Coast, QLD 4222, Australia; \\ s.baker@griffith.edu.au \\ * Correspondence: p.tacon@griffith.edu.au \\ † These authors contributed equally to this work.
}

Received: 20 April 2019; Accepted: 2 May 2019; Published: 4 May 2019

\begin{abstract}
In the past decade, scholarship has documented the ways in which interacting with different forms of heritage impact individual and/or community well-being, as well as the harm to human well-being that occurs when heritage is damaged or destroyed. We bring the results of a review of this literature together, defining both heritage and well-being in relation to each other and exploring the relationship between heritage and well-being. New and emerging threats to heritage and, in turn, well-being are outlined, as well as new ways of preserving heritage for future generations. The future of heritage is discussed along with the importance of the concept of "living heritage". We conclude that heritage is essential for contemporary and future well-being, and that if we do not better care for heritage then human health will be negatively impacted.
\end{abstract}

Keywords: heritage; well-being; conservation; digitization; preservation; culture; health

\section{Introduction}

In the past decade numerous studies have been published on how different forms of cultural and/or natural heritage impact on human well-being. For instance, it has been argued by many researchers of various disciplinary backgrounds that meaningful encounters with a wide range of different types of heritage can positively enhance a sense of individual and community well-being. On the other hand, damage to heritage can have a demoralizing effect, leading to diminished well-being. Well-being has been defined in many ways but essentially it is a sense of being content, comfortable and happy, something normally associated with physical, mental and emotional health as well as a standard of living that provides the resources to sustain such health, although the nature of this varies across cultures past and present. So how can heritage affect one's sense of well-being? This is essentially what we seek to explore in this review essay by touching upon some of the key results presented in recent literature on heritage and well-being. In order to do this, we further define both heritage and well-being below, as well as the complex relationship between the two. We also review some of the challenges that heritage faces and argue that human well-being is best enhanced by viewing heritage as an essential part of the contemporary world rather than fragments of the past, and that the concept of "living heritage" is useful in this sense. Thus, the overarching thesis of this article is that all heritage is an important part of contemporary culture, and that threats to heritage impact on individual and community well-being in multiple ways. However, heritage is also contested and one of the biggest challenges is deciding what heritage should or should not be preserved for future generations as well as how this will be undertaken.

By offering a broad consideration and appraisal of recent scholarship, our intention in this article is to shift the focus of heritage discourse from one that is primarily specific place or topic driven to instead consider how heritage more generally is used to reinforce, negotiate or suppress contemporary 
relationships between people, places and identity. By engaging with these questions and issues through a consolidation of understandings presented across a wide-ranging array of literature, we offer insight into the contemporary significance and value of tangible and intangible heritage. This is important because in an increasingly changing political, environmental and cultural world, new and emerging threats to many different aspects of heritage will impact on human well-being.

\section{Literature Review}

\subsection{Links Between Heritage and Well-Being}

Increasingly, links are being made between various aspects of heritage and its relationship to well-being. In addition to notable books that touch upon these links such as Museums, Health and Well-Being [1], Human Well-Being and the Natural Environment [2] and Heritage and Community Engagement [3], recent articles have appeared in a broad array of disciplinary journals on issues including the impact of archaeological excavations on happiness [4], the therapeutic effects of community-based heritage conservation [5], and how the aesthetic experience of heritage sites can reduce stress [6]. While well-being is rarely indexed in major heritage handbooks or readers [7-10], there is a growing body of literature indicating that cultural heritage, including rock art [11], ancient architecture [12], written heritage [13], material culture [14] and intangible cultural practices [15], is very important for contemporary well-being for diverse groups of people.

For instance, the protection of heritage is central to the health of Aboriginal Australians and a number of recent studies have highlighted the strong relationship between Indigenous well-being, cultural heritage and environment [16-20]. Connections between rock art heritage and Indigenous well-being have recently been explored in Australia [11], as has the contemporary importance of such sites for Indigenous and non-Indigenous people worldwide [21].

Heritage related to the more recent past has also been found to impact well-being. Research conducted on community heritage sector organizations working to preserve popular music histories suggests that these museums and archives function as "third places" [22], which promote a sense of well-being for the, especially older, volunteers who work for them [23,24]. The Australian Jazz Museum, for example, was found to be "a caring environment, benefiting the individuals who engage with it by meeting the needs necessary to support the mental, emotional, physical and social well-being of volunteers - and the wider community - by preserving localized popular music heritage, and by supporting the social lives and health of ageing adults" [25] (p. 11).

Visiting heritage sites has also been highlighted to be very beneficial to well-being [26]. By using a "non-market valuation approach, known as Wellbeing Valuation, that relies on people's self-reported wellbeing and that offers a solution to many of the anomalies observed in preference-based valuation methods", Fujiwara and colleagues concluded that visiting heritage sites has a greater impact on well-being than attendance at sporting events [27] (p. 9) [28]. Research has also shown that visiting museums and galleries improves the health and well-being of people of vastly different socio-cultural and ethnic backgrounds [29] (see special issue of the journal Arts $\mathcal{E}$ Health 2015, volume 7, number 3 on Culture, Museums and Wellbeing). Indeed, as Livni reports, in Montreal, Canada doctors are now giving patients prescriptions for free art museum visits in order to enhance well-being [30] (n.p.):

"In the 21st century, culture will be what physical activity was for health in the 20th century," predicts Nathalie Bondil, Montreal Museum of Fine Arts director general, in the Montreal Gazette. The innovative institution is already focused on art and wellness. It created The Art Hive, a community studio supervised by an art therapist where visitors can create themselves, and programming that promotes well-being through art, as well as research collaborations with physicians on the health benefits of museum visits, and a medical consultation room. Now, it's joining forces with Médecins Francophones du Canada, an association of French-speaking doctors, to allow member physicians to prescribe art. Hélène Boyer, vice president of the medical association, explained to the Gazette: "There's more and more scientific proof that art therapy is good for your physical health. It increases 
our level of cortisol and our level of serotonin. We secrete hormones when we visit a museum and these hormones are responsible for our well-being.

In a very different study on heritage and contemporary well-being, Brady and Taçon [21] have shown how world rock art is not just a part of archaeology and the distant past but it also has much contemporary importance and remains a part of living culture in many societies. Threats to rock art therefore threaten contemporary well-being [11,31-33]. From this and the other examples above, it can be seen that connections between heritage and well-being are being made across the arts, humanities and social science disciplines, as well as the fields of health and medicine, demonstrating that heritage has contemporary value not just in economic, historic or cultural terms but also as something that contributes to human welfare.

\subsection{Better Defining Heritage and Well-Being in Relationship to Each Other}

In its broadest sense, heritage can be defined as everything humans have experienced and made since the dawn of human consciousness. Heritage includes natural landscapes and biota as well as the products of thousands of cultures over tens of millennia up to the very recent past, and for many people natural and cultural heritage are intimately linked as parts of a greater whole that should not be separated. What heritage is deemed important, good, bad or of no value varies between individuals, groups, communities, cultures and nations. Because it is impossible to save and pass on all heritage, heritage is categorized, evaluated and authenticated so what is believed to be most important is passed on to/inherited by future generations. However, some heritage can be deeply personal, something difficult or even impossible for some other people to understand or empathize with. This makes decisions about what heritage and whose heritage to protect complex and in the past many biases have contributed to both the destruction and protection of heritage.

In terms of well-being we follow Taçon's definition in relation to its intersection with heritage [11] (p. 6):

Well-being can be defined in many ways, including social, personal, economic, cultural, environmental, psychological, spiritual, physical. Most importantly, it can be viewed as a positive sense of personal and cultural wellness that results from strong cultural identity. Strong cultural identity is underpinned by connection to places, landscapes, tradition, heritage, shared stories and communal histories. Thus, well-being is here defined as a positive sense of psychological, physical, emotional and spiritual satisfaction that results from being part of a culture and community that actively engages with its environment, heritage and traditions. Consequently, when heritage ... is damaged, destroyed or threatened the well-being of individuals and communities is negatively impacted.

Thus, heritage and human well-being are linked at many levels, with the relationship both complex and convoluted. For instance, according to Monckton and Reilly some of the ways interacting with heritage promotes well-being for individuals and communities includes [26] (p. 14):

- Combining physical activity with outdoors and cultural heritage

- Forming a new relationship with the past that creates new perspectives

- Utilising and developing skills and feeling meaningful through contributing productively to something

- Providing social interaction and creativity that relates to links with the past

- Creating a long-lasting benefit through increased self-awareness and social networks

- Developing a wider collective sense of community, belonging and equality of inclusion through place-based initiatives.

Measuring the strength of the heritage well-being relationship is a significant challenge. As Sayer [34] argues, connections between heritage and well-being made by scholars including Darvill [35], Holtorf [36] and Renfrew [37] have rarely been supported by quantitative or qualitative 
evidence. Sayer proposes that measures like the visual analogue scale [38] and the positive and negative effect schedule [39] are tools which enable changes in well-being to be measured over time. Anthropological perspectives, however, caution against "an over-preoccupation with measuring wellbeing ... as concentrating on universal indexes may be done in detriment to other ways of knowing and understanding human wellbeing practices" [40] (pp. 1-2). Much of the evidence of the impact of heritage on well-being is anecdotal [5], suggesting that even when the nexus is not measured definitively using qualitative and quantitative tools, the heritage well-being relationship can nevertheless be observed.

\section{Analysis of Results}

Given the heritage well-being relationship established in recent literature, it follows that threats to heritage threaten well-being. Of course, natural disasters such as earthquakes, storms, fire, flood, insects (especially termites), other creatures, environmental change and neglect have always threatened heritage and human well-being in many ways. However, despite its importance for individual, group, community and national well-being, heritage is threatened globally by development and cultural intolerance [41] with the destruction of heritage increasingly used to disempower people. The destruction of cultural heritage sites, such as that systematically undertaken by Islamic State in Syria and Iraq is an extreme example, but it also raises questions about the sustainability of heritage sites and practices, as well as the motivations in terms of purposeful negative impact on individual and community well-being [42-45].

\subsection{Colonialism and the Erasure of Heritage}

Having access to, and engaging with, local heritage can enhance a sense of community identity and well-being. When this access and engagement is connected to community attachments to place, feelings of civic pride and belonging may be strengthened. In the case of (re-)colonization of small islands, the erasure of heritage can be a strategy to weaken a community's claims to self-governance and determination with subsequent impacts on the experience of heritage and well-being - as can be observed on the small Pacific island of Norfolk Island. Following the assent on 26 May 2015 of the Norfolk Island Legislation Amendment Bill, the Australian Government abolished the Norfolk Island Legislative Assembly, an Assembly described by Nobbs [46] (p. 47) as a "world-noteworthy experiment in small-island democracy which persisted for over 35 years", and which is "as much a part of the heritage value" of the Kingston and Arthur's Vale Historic Area (KAVHA) World Heritage site as the built heritage, ruins and remnants of the convict settlements that KAVHA also contains. Without the knowledge of the Norfolk Island community, in September 2015 the material remnants of the Assembly, were removed from the Old Military Barracks in KAVHA, "including the horseshoe Assembly Chamber table and chairs, the Speaker's Bench, the large committee room table, furniture, flags and decorated wall holders, gifts, plaques, coats of arms, photographs, and Norfolk Island seal" [46] (pp. 46-47). Nobbs states in his book Australia's Assault on Norfolk Island, 2015-2016, "all these tangible elements of heritage were in place when the World Heritage Council granted World Heritage status to the site" and that their removal constitutes unacceptable conduct [46] (p. 47). Nobbs makes a direct connection between the removal of this heritage and the purposeful erosion of the well-being of Norfolk Islanders, with the act part of the Australian Government's "deliberate attempt to write "Norfolk Islandness" out of history" [46] (p. 49). The erasure of heritage in the present-day colonialism of Norfolk Island by the Australian Government works to further displace and subjugate Norfolk Islanders, particularly those of Pitcairn descent, placing the well-being of this small island community at threat.

\subsection{Monuments}

For thousands of years humans have produced various forms of monuments around the world to mark the locations of significant human experience. However, the celebration of heritage in the 
form of monuments, can also be problematic when serving to remind people of their disempowerment. The 2017 removal of a number of Confederate monuments, statues and markers across the United States of America drew attention to the very real impact the presence of Civil War markers can have on present day African-Americans whose descendants, both enslaved and free, suffered as a result of the Confederacy's actions [47]. As the Mayor of New Orleans, Mitch Landrieu, argued in defense of the city's removal of four Confederate monuments: "They are not just innocent remembrances of a benign history. These monuments celebrate a fictional, sanitized Confederacy ignoring the death, ignoring the enslavement, ignoring the terror that it actually stood for" [48] (n.p.). But Samuels notes [47] (p. 122):

The public discussions following Charlottesville on "what to do" with the statue and similar commemorations illuminate several points that are relevant to theoretical understandings of heritage under debate by heritage scholars and practitioners. Firstly, the fallout following Charlottesville provides a lens on the importance of the "cultural" modifier of "cultural heritage," and secondly, argues for the importance of the public sphere to understandings of what it is that this idea of "heritage" does-what its function is -in modern society.

These arguments resonated in Australia, where the tearing down of monuments in the US prompted questions to be asked about the impact of historical markers that celebrate colonization. Prominent Aboriginal journalist Stan Grant noted that the inscription on Captain Cook's statue in Hyde Park, Sydney, which states Cook "Discovered this territory 1770", maintains a damaging myth of terra nullius, which serves to render Australia's Aboriginal people "invisible"— "History itself becomes a hymn to whiteness" [49] (n.p.). Similar calls for the removal of monuments, statues and other forms of heritage markers linked to colonialism have occurred elsewhere, such as in South Africa where, as Barnabas asserts, the skewed "commemorative landscape" with its "symbolically loaded" monuments [50] (p. 114) has resulted in "bitter contestations over hegemonic narratives" inscribed in collective memory by way of these legitimated purveyors of heritage [50] (p. 111). So here we have a conundrum - the preservation of one group's heritage enhances their sense of well-being and power but negatively impacts on the well-being of other groups.

\subsection{Heritage Sustainability}

Even if there is agreement between groups on what heritage should be preserved there is the challenge of heritage sustainability in the face of development and cultural change, a growing issue the world over. This is summed up succinctly for the Hul'qumi'num Coast Salish peoples of British Columbia, Canada [51] (p. 72):

Hul'qumi'num peoples express deep concerns over their inability to maintain their customary laws with regard to the protection of their archaeological heritage. Modern land politics represents a significant challenge for Hul'qumi'num peoples, and it threatens their ability to maintain their historical connections to their lands and, most notably, their ability to protect archaeological sites located on private property. Hul'qumi'num argue that the provincial government and the heritage resource industry are undermining their customary laws, which are what enable them to rightfully and appropriately manage their aboriginal heritage. Although issues external to the community are the primary focus of concern, issues within the community also need to be addressed.

Heritage sustainability is a wide-ranging issue that cuts across an array of interrelated themes including heritage ownership, citizenship and peace building, respect for diversity, political contexts and participation [52]. Contemporary heritage institutions and indigenous community heritage programs face issues of sustainability due to a dearth of resources in terms of funding, human capital and external support, a situation particularly acute in the community heritage sector. Sustainability has emerged as an important theme across the heritage sector, garnering increasing importance in the consideration of "the conservation of historic sites, monuments, and landscapes" due to an understanding of "cultural heritage as contributing in significant ways to broader efforts to create 
sustainable societies" [53] (p. 8). However, the accompanying rise in heritage tourism poses a challenge to sustainability (see Figure 1). As Barthel-Bouchier notes, "as the physical evidence of the costs of tourism and development to both the historic and the physical environment grows, so too do political tensions and a sense that heritage conservationists have not yet decided exactly how conservation of the past can contribute fully to a sustainable future" [53] (p. 9). Addressing the sustainability of heritage sites and practices is interlinked with understanding the role of heritage in promoting and securing the well-being of those people to whom the heritage has cultural meaning.

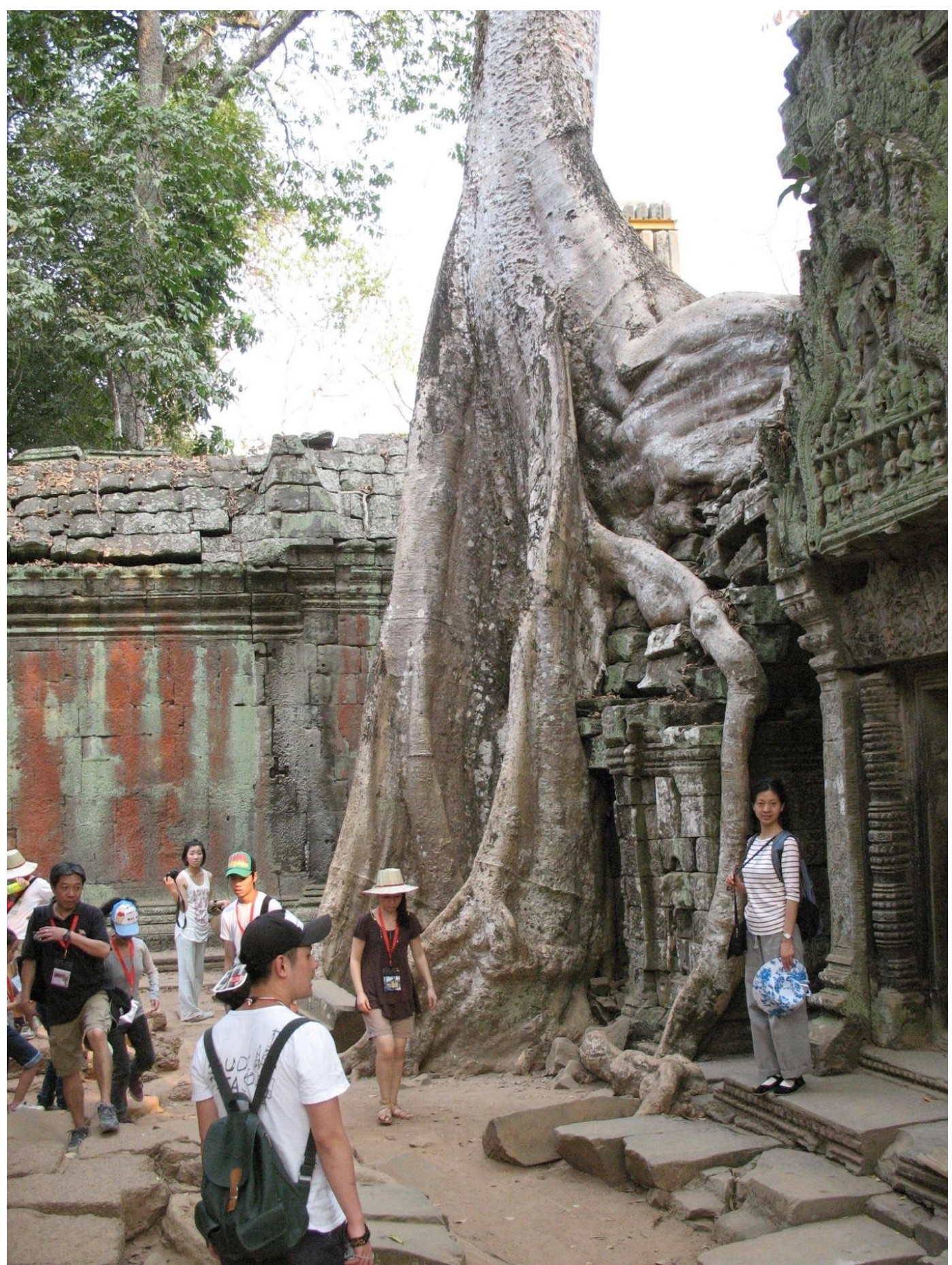

Figure 1. Angkor Wat, Cambodia, 2011. Challenges to this heritage landscape include the roots of enormous trees and tourists (Photograph by Paul S.C. Taçon). 
Heritage sustainability is a particular challenge for unintentional heritage sites such as those found on social media platforms in which archival practices have emerged despite users not having the original intent to preserve or archive the materials they upload [54]. The challenge of sustainability can be observed in the case of the Myspace platform which was reported in early 2019 to have permanently deleted approximately 50 million songs by 14 million artists uploaded prior to 2015 due to an unsuccessful server migration. The platform was never intended to be used as an online archive, and users of the platform are unlikely to "consider themselves to be archivists or involved in the act of archiving", but the deletion of materials acts to remove from public access items from popular music's past, "subsequently, taking it out of heritage's reach" [54] (p. 482). In the case of Myspace and other social media platforms, the threat to the sustainability of unintentional archives "is tied up with the commercial aims and objectives, terms and conditions, and the online architecture imposed by the corporation which dictates how communities are able to grow and sustain themselves and their collections" [54] (p. 480). The impact on well-being is emerging through posts about the Myspace debacle that have appeared on another social media platform Reddit, with one user noting: "My son recorded a song when he was 7 years old that his guitar instructor uploaded to his Myspace page. My son died 2 years ago, at the age of 20, and I would do anything to be able to hear it again" [55] (n.p.).

\section{Discussion}

Following the addition of 20 places from various parts of the world at the 42 nd session to inscribe natural and cultural sites, held between 24 June and 4 July 2018, there were 1092 properties on UNESCO'S World Heritage List. But will this afford these newly listed sites better protection or bring new threats such as mismanaged, inaccurate or inappropriate tourism $[56,57]$ ? And what of the future of heritage sites not on the list? For instance, across the globe, all heritage is threatened by increasingly frequent natural disasters such as earthquakes, volcanoes, hurricanes, wild fires and more general climate change. As Harvey and Perry [58] (p. i) note in the introduction to one of the few books devoted to the topic of the future of heritage in relation to climate change, 'Climate change is a critical issue for heritage studies. Sites, objects and ways of life are all coming under threat, requiring alternative management or requiring specific climate change adaptation". Also, sites and other forms of both tangible and intangible heritage are threatened by development including mining, new forms of terrorism and technological warfare, abandonment and neglect.

In a 2013 paper on the future of heritage, Högberg and Holtorf [59] (p. 739) emphasize that "the heritage sector has failed to give sufficient attention to future issues" and argue that "this short-coming should be remedied as soon as possible". They also state "that the heritage sector lacks a thorough engagement with questions concerning the future benefits of cultural heritage and thus concerning the appropriateness of present-day practices and policies in heritage management". This is still very much true today [60]. Cultural theorist Patricia Wise succinctly expressed this at the local level in communication with the authors in 2016 [61]:

To understand and work effectively with the intersections between heritage and well-being we need to begin with individuals and communities in local and regional settings. Personal attachments, community celebrations, private distress and public resistance have their origins in taken-for-granted relations that become intensities when they are threatened by change, development or neglect. Often it can be particularly difficult to anticipate where, when and how residents will take action. This unpredictability highlights how locals and visitors are too readily assumed to view heritage in terms of sites and practices of high and deep cultural value - historic, spiritual, aesthetic, architectural, environmental, and popular. Can we establish the heritage value of a surf break? A bush track? The view from the seventy-first floor? A corner store? How is heritage operating when what is at stake is people's feeling that "the place just won't be the same"? We can be as much attached to minor heritages - traces and accidents of nature and history - as to conventional repositories of shared meaning. What if we begin by identifying what people value about where they live? That is, let's ask 
people how their region caters for their well-being. Their answers to that question will suggest how we might map regional heritage more productively.

The future of heritage, human well-being and healthy societies is something of increasing importance as the world undergoes unprecedented cultural and environmental change fueled by new digital technology, robotics, shrinking natural resources, human population growth, species extinctions, global warming and shifting political landscapes. Human well-being and healthy societies are threatened by a multitude of growing factors, and for many people the future seems more uncertain than ever before. The role of heritage in mitigating some of this change and how the loss of heritage compounds the effects of rapid change in terms of contemporary human well-being are important issues that are in need of better discussion. This is because their exploration may allow us to chart a different future, grounded in the past [62], a future with heritage celebrated as a cornerstone of human identity, accomplishment, dignity and respect. In emphasizing the importance of heritage for the present and future, Meskell eloquently expresses the interconnections [63] (pp. 1-2):

Whether for the social performance of memory, trauma, protest, or uplift, a material past is discursively assembled to serve as a physical conduit between past and present. Since sites and objects bear witness to particular pasts and have those histories woven into their very fabric, they physically embody and instantiate the past in the present in a way that no textual account can fully achieve. That being said, we have increasingly come to see what many indigenous communities have long realized and indeed practiced: that these physical landscapes, monuments, and objects cannot be separated from intangible beliefs and resonances. The artificial separation of these traits is itself a symbolic violence. And when the immaterial connection that people experience disappears, the significance of those same sites and objects may also decline in the public imaginary.

With heritage under threat from so many directions, and people's well-being negatively impacted by the mismanagement, demise and destruction of heritage, the time to find ways to future-proof tangible and intangible heritage is now.

\section{Digital Heritage as a Form of Preservation}

One of the biggest changes in recent years for heritage in terms of preservation is the use of digital technologies [64]. 3D modelling and scanning is now becoming commonplace, as is social media as a form of heritage preservation, contributing to conservation but with new problems [65-67]. Indeed, it is becoming an integral tool for analysis and presentation of information for heritage preservation, as Pieraccini and colleagues [68], Silberman [69] and Lerma and colleagues [70] have demonstrated. Silberman [69] has also shown various other ways technology aids the preservation of heritage. Building on earlier photogrammetric recording with film cameras at rock art sites, digital 3D scanning and modelling of rock art began in the mid-2000s, including pioneering research in Australia and the UK [71-73]. Varied forms of 3D recording are now becoming commonplace in rock art studies, especially in Europe [74-77] and increasingly in Australia [78]. Digital inventories of heritage are also becoming more common $[79,80]$ and many major national and international 3D heritage projects have commenced in the past decade [81]. Furthermore, cross-platform mobile applications available to the general public are also aiding heritage conservation [82] and the public's involvement has well-being benefits.

However, to what extent do these forms of heritage preservation enhance well-being? Increasingly, there are arguments that there are negative or no effects [83-85]. For instance, Thomas [86] (p. 201) is of the opinion that "digital technologies reduce the past to a pattern of pixels, viewed on the screen of modern rationalism", a form of projection, both figurative and literal, devoid of materiality and passed through a filter, consequently reducing meaning. Baker takes this further, arguing there is a digital danger [83] (p. 2):

There is also a danger with working on cultural heritage with digital tools. The problem put simply is that the technology available to animators, designers, programmers and game designers is so powerful 
that it can take control and produce a past more "real" than the archaeological remains allow. The most extreme forms are some historically based computer games with CGI visuals, but the problem can also extend to many fly-through architectural reconstructions, which form a kind of hyperreal past that demonstrates very well the technical prowess of the designer and the software used, but goes well beyond the archaeological base upon which these reconstructions should be based. The problem is, who is the author of an exhibition or a video - the researcher or the designer? One is the expert for the data, the other for the software? To take sporting analogy is the archaeologist a player manager, a trainer or the referee? I would say the core function is one of referee. Someone who keeps an eye on the rules of academic research and looks out for fair play towards the powerless prehistoric creators of the material record.

Another digital danger for well-being is that digital recordings of heritage destruction can and have been used to maximise the negative impact on individual, community and cultural well-being such "that the use of digital technology and production techniques allows the iconoclasm to be globally disseminated and permanently stored in digital archives for posterity" [45] (p. 667).

On the other hand, 2D digital recordings, digital video and 3D reality capture of heritage items are important because they are non-invasive methods that not only preserve and protect these items but also can create an accurate model of irreplaceable memories (good and bad), forever communicating the stories of past civilizations and events to future generations. 3D reconstructions also provide people who may not normally have the opportunity to experience an artefact, building, site or place a way to connect, albeit virtually. Galeazzi concludes [84] (p. 278):

The discussion about the value of virtual reconstruction for the preservation and interpretation of cultural heritage has only just started. Should these virtual simulations be considered original digital representations of our cultural heritage or just virtual "fakes"? They can probably be considered subjective virtual interpretations (a relative "authentic") that aim to get as close as possible to the absolute "authentic" thanks to the activation of a multisimulation process and the creation of "open" and "dynamic" ontologies. This kind of process can allow users to compare, virtually and in real time, different reconstructed worlds that result from diverse interpretations of the same cultural heritage and to then change them and create new interpretations. New digital methodologies can facilitate the preservation of our material memory and, at the same time, help to remove the barriers between past and present through innovative and open communication systems.

The pace of technological change, especially in terms of IT, digitization software and hardware, $3 \mathrm{D}$, virtual reality and so forth, is such that soon there should be new ways to preserve and reconstruct important heritage. Whole virtual worlds may one day exist to give people incredibly realistic immersive heritage experiences that will educate, enrich and nurture well-being. Virtual time travel will be possible and heritage experiences currently articulated through science fiction could one day become commonplace. Great "Creativity Places" will be built where "visitors will encounter a convergence of art, science and technology" [87] (p. 214). There will be a focus on our shared human heritage so Creativity Places are "designed not just to display the incredible range of past and present achievements but also to inspire new creations, debate and reflection" [87] (p. 216).

\section{Conclusions}

Inspiration, debate and reflection is always needed when addressing challenges to heritage and well-being. This is because, as Colwell and Joy [88] (p. 122) state, "In practice, multiple compromises take place on all sides when considering the stewardship of cultural heritage". One of the biggest challenges for the future is how to maintain heritages places as living places, as Ndoro and Wijesuriya summarize [89] (p. 135):

A regional comparison of traditional heritage management reveals a shared principle of usable and living heritage. Heritage places such as Timbuktu, Aksum, Great Zimbabwe, and Kilwa, among 
others, were not left to decay, waiting for "discovery" by foreign heritage experts. Many archaeological sites and ruins, for example Anuradhapura in Sri Lanka, Lumbini in Nepal, Bodhgaya in India, and many other sites, are still places of worship and pilgrimage and are considered sacred by millions of Buddhists. These places contain archaeological remains dating back to the third century BCE, but their sacredness adds a different set of values and conservation challenges. Most of these places still play major roles as part of a dynamic cultural landscape whose meaning is derived from its wider social and religious context.

The idea of living heritage resonates beyond the kinds of heritage places referred to by Ndoro and Wijesuriya. Research on the motivations of community heritage sector volunteers to continue their efforts to preserve material culture under challenging organizational circumstances, has demonstrated the importance placed on institutions to be "living archives" or "living museums" [23]. While volunteers often used this terminology to compare their do-it-yourself approach to heritage management to what they perceived to be the "dusty" approach of more traditional heritage institutions, they also emphasized that community heritage organizations are "institutions for living", that is, places that nurture the well-being of volunteers and visitors, but also the well-being of objects through the love and care volunteers hold for their collections. These living archives and museums are "dynamic holders of history and memory that enliven" communities and where "the past is folded into the present through collective memory-making and identity-building by those moving through and interacting within the space" [23] (p. 77; see also pp. 78-79). Volunteering in the community heritage sector is "life-sustaining" for those who give their time to this activity and this, in turn, can be "life-sustaining for the institution" [23] (p. 109).

Thus, we argue that it is critical for all heritage to be imagined as living heritage — - as not being solely of the past, but equally about the present and future-and that this approach to heritage is what will better ensure it will be safeguarded in years to come. In the process, the well-being of participants will be enhanced. For instance, "While visiting meaningful places brings a whole host of benefits, these can be broadly grouped into three key areas - mental wellbeing, nostalgia and security and survival. Natural places in particular promote greater wellbeing, as well as places from the here and now" [90] (p.40). In Australia, Aboriginal people contend rock art sites in natural-cultural landscapes are significant parts of contemporary living heritage and this is true for some Indigenous communities in Africa, the Americas and elsewhere [21]. Because of this it has recently been argued by Agnew and colleagues that in order to best conserve rock art eight "Foundation Principles" need to be adhered to throughout the world [31] (p. 4):

Principle 1 Work actively to promote rock art as a valuable heritage for everyone, and allocate sufficient resources specifically to its future care

Principle 2 Manage to protect all values

Principle 3 Preserve and manage rock art as an inherent part of the landscape

Principle 4 Safeguard cultural rights and practices

Principle 5 Involve and empower Indigenous owners and local communities in decisions about rock art management and conservation

Principle 6 Use recognised ethics, protocols and standards for documentation, conservation and interpretation as the basis for management practice

Principle 7 Give priority to preventive and protective conservation

Principle 8 Make effective communication and collaboration a central part of management

We strongly suggest that these principles should not just pertain to the world's rock art heritage. Rather, they should be modified to underlie all heritage conservation. In this way we should be able to not only better address present and new heritage threats and challenges but also maximize the return for individual and community well-being in relation to heritage. Furthermore, as Monckton and Reilly [26] (p. 11) argue "Wellbeing relates most closely to the neighbourhood, whether through local 
action, connecting with local people and groups or our local environment. By extension, therefore, wellbeing can be best linked with the heritage of the everyday".

A recent National Trust (UK) study concluded $92 \%$ of people "would be upset if their meaningful place was lost" [90] (p. 36). This was recently demonstrated in Paris with the tragic fire at Notre Dame cathedral and the outpouring of grief across Paris, France and the world more generally. Instantly a commitment to rebuild was made and billions of euros of funding donated. The new Notre Dame will be a mix of new and old materials, perhaps diminishing authenticity but maintaining the sense of wonder produced for its public [91]. Heritage is destroyed all the time. Notre Dame has global value. Yet, there are lots of other examples that do not have mass appeal to broad international audiences, but which are equally effective at enhancing well-being while extant and negatively affect well-being when damaged or destroyed. It is also important to emphasise the ever-evolving space heritage and well-being has. For instance, recently there have been arguments for preserving ruins rather than restoring them. DeSilvey [92] argues that for well-being, we also need to learn to let go rather than to adhere to (mainly Western) rules of preservation. Can we or should we save everything and have we already accumulated too much as DeSilvey, Harrison [93] and some others suggest?

However, from our review of literature that touches on the heritage well-being nexus, we conclude that unless we take better measures to conserve and interpret natural and cultural heritage in contemporary contexts, the future psychological and even physical health of both individuals and societies will increasingly be at risk. Heritage is not a romantic, nostalgic component of fragmented pasts and memories but rather an essential part of who and what we are, where we have come from and where we are going. Heritage is something that is essential for contemporary and future well-being.

But where do we go from here? How can we reframe the debate about heritage futures and priorities? We believe one of the biggest challenges to the future of heritage is what do we do with all of this stuff? How do we best decide what to keep and what to abandon? Whose heritage takes priority and how can we better encourage respect for the heritage of other people and not just our own or what we think is important? How can heritage preservation be more egalitarian? And by declaring something as having high or exceptional heritage value, do we create new threats to that heritage in terms of people desiring access to it? Furthermore, given the multitude of recent studies showing the value of heritage to human well-being, how do we provide more meaningful and more frequent interactions with heritage? The concept of living heritage as referred to above is most useful in this sense. The conclusion to Poulios' case study from Greece [94] expresses this succinctly [94] (p.139):

\begin{abstract}
A living heritage approach tends to radically redefine the existing concept of heritage and the principles of heritage conservation by challenging, for the first time in the history of conservation, very strong assumptions established over time in the field, which were developed along with a material-based approach and were maintained by a values-based approach ... More specifically, according to a living heritage approach, first, the power in the conservation process is [no] longer in the hands of the conservation professionals, but passes on to the communities. Second, emphasis is no longer on the preservation of the (tangible) material but on the maintenance of the (intangible) connection of communities with heritage, even if the material might be harmed. Third, heritage is not considered a monument of the past that has to be protected from the present community, for the sake of future generations; heritage is now seen and protected as an inseparable part of the life of the present community. Thus, past and present-future are not separated (discontinuity), but unified into an ongoing present (continuity). Therefore, a living heritage approach attempts to mark the shift in heritage conservation from monuments to people, from the tangible fabric to intangible connections with heritage, and from discontinuity to continuity.
\end{abstract}

We see this as the biggest challenge of all in the heritage well-being relationship-shifting the longstanding Euro-American derived approach to heritage, that focuses on objects, monuments and the built environment as in the World Heritage concept, to a focus on living peoples living in and interacting with heritage as a meaningful part of the rest of their lives. In this way, all of the questions listed above can be better addressed with positive outcomes for both heritage and human well-being. 
Author Contributions: Both authors contributed equally to the ideas in this paper as well as to the writing and development of the article. Although P.S.C.T. took the lead on writing and editing, S.B. provided additional breadth and scope as well as literature discussion for each section.

Funding: This research was funded by an Australian Research Council Laureate Fellowship (FL160100123) awarded to Taçon. Additional funding was provided by a small grant from the Griffith Centre for Social and Cultural Research awarded to Baker and Taçon.

Acknowledgments: We thank the Australian Research Council and Griffith University for supporting this research which began in November 2016. Thanks also to Professor John Schofield for an inspiring heritage workshop with our PhD students researching varied aspects of heritage held at Griffith University in March 2019 that encouraged us to finalize and publish our results.

Conflicts of Interest: The authors declare no conflict of interest.

\section{References}

1. Chatterjee, H.; Noble, G. Museums, Health and Well-being; Ashgate: Farnham, UK, 2013.

2. Dasgupta, P. Human Well-Being and the Natural Environment; Oxford University Press: Oxford, UK, 2001.

3. Waterton, E.; Watson, S. Heritage and Community Engagement: Collaboration or Contestation; Routledge: Milton Park, UK, 2010.

4. Sayer, F. Can digging make you happy? Archaeological excavations, happiness and heritage. Arts Health 2015, 7, 247-260. [CrossRef]

5. Power, A.; Smyth, K. Heritage, health and place: The legacies of local community-based heritage conservation on social wellbeing. Health Place 2016, 29, 160-167. [CrossRef]

6. Grossi, E.; Blessi, G.T.; Sacco, P.L. Magic moments: Determinants of stress relief and subjective wellbeing from visiting a cultural heritage site. Cult. Med. Psychiat. 2019, 43, 4-14. [CrossRef] [PubMed]

7. Fairclough, G.; Harrison, R.; Jameson Jnr, J.H.; Schofield, J. The Heritage Reader; Routledge: New York, NY, USA, 2008.

8. Graham, B.; Howard, P. The Ashgate Research Companion to Heritage and Identity; Ashgate: Farnham, UK, 2008.

9. Logan, W.; Craith, M.N.; Kockel, U. A Companion to Heritage Studies; Wiley Blackwell: Oxford, UK, 2016.

10. Waterton, E.; Watson, S. The Palgrave Handbook of Contemporary Heritage Research; Palgrave: New York, NY, USA, 2015.

11. Taçon, P.S.C. Connecting to the Ancestors: Why rock art is important for Indigenous Australian and their well-being. Rock Art Res. 2019, 36, 5-14.

12. Gražulevičiūtè, I. Cultural heritage in the context of sustainable development. Environ. Res. Eng. Manag. 2006, 3, 74-79.

13. Fujiwara, D.; Lawton, R.; Mouratao, S. The Health and Well-Being Benefits of Public Libraries. Full Report; Arts Council England: Manchester, UK, 2015.

14. Ander, E.; Thomson, L.; Noble, G.; Lanceley, A.; Menon, U.; Chatterjee, H. Heritage, health and wellbeing: Assessing the impact of a heritage focused intervention on health and wellbeing. Int. J. Herit. Stud. 2009, 19, 229-242. [CrossRef]

15. Simpson, M. Museums and restorative justice: Heritage, repatriation and cultural education. Mus. Int. 2018, 61, 121-129. [CrossRef]

16. Byrne, D. Partnerships in the heritage of the displaced. Mus. Int. 2004, 224, 89-97. [CrossRef]

17. Byrne, D.; Nugent, M. Mapping Attachment: A Spatial Approach to Aboriginal Post-Contact Heritage; Department of Environment and Conservation: Hurstville, Australia, 2004.

18. Carrington, B.; Young, P. Aboriginal Heritage and Wellbeing; Department of Environment, Climate Change and Water (NSW): Sydney South, Australia, 2011.

19. Grieves, V. Indigenous Wellbeing: A Framework for Governments' Aboriginal Cultural Heritage Activities; Department of Environment and Conservation: Hurstville, Australia, 2006.

20. Sutton, M.-J.; Huntley, J.; Anderson, B. "All our sites are of high significance”, reflections from recent work in the Hunter Valley-Archaeological and Indigenous Perspectives. J. Aust. Assoc. Consult. Archaeol. 2013, 1, 1-15.

21. Brady, L.; Taçon, P. Relating to Rock Art in the Contemporary World: Navigating Symbolism, Meaning and Significance; University Press of Colorado: Boulder, CO, USA, 2016. 
22. Oldenburg, R. The Great Good Place: Cafes, Coffee Shops, Bookstores, Bars, Hair Salons, and Other Hangouts at the Heart of a Community; Hachette Books: New York, NY, USA, 1999.

23. Baker, S. Community Custodians of Popular Music's Past: A DIY Approach to Heritage; Routledge: New York, NY, USA, 2017.

24. Istvandity, L.; Baker, S.; Collins, J.; Driessen, S.; Strong, C. Understanding popular music heritage practice through the lens of third place. In Rethinking Third Places: Informal Public Spaces and Community Building; Dolley, J., Bosman, C., Eds.; Edward Elgar: Cheltenham, UK, 2019.

25. Cantillon, Z.; Baker, S. DIY heritage institutions as third places: Caring, community and wellbeing among volunteers at the Australian Jazz Museum. Leis. Sci. 2018. [CrossRef]

26. Monckton, L.; Reilly, S. Wellbeing and historic environment: Why bother? Exploring the relationship between wellbeing and the historic environment. Hist. Engl. Res. 2018, 11, 6-17.

27. Fujiwara, D.; Cornwall, T.; Dolan, P. Heritage and Wellbeing; English Heritage: London, UK, 2014.

28. Maeer, G.; Robinson, A. Values and Benefits of Heritage: A Research Review; Heritage Lottery Fund Strategy and Business Development Department: London, UK, 2015.

29. Frogett, L.; Roy, A. Cultural Attendance and Public Mental Health: Evaluation of Pilot Programme 2012-14; Manchester City Council: Manchester, UK, 2014.

30. Livni, E. Doctors in Montreal Can Now Prescribe a Visit to an Art Museum. World Economic Forum (26 October 2018). Available online: https://www.weforum.org/agenda/2018/10/doctors-in-montreal-willstart-prescribing-visits-to-the-art-museum (accessed on 25 March 2019).

31. Agnew, N.; Deacon, J.; Hall, N.; Little, T.; Sullivan, S.; Taçon, P.S.C. Rock Art: A Cultural Treasure at Risk; The Getty Conservation Institute: Los Angeles, CA, USA, 2015.

32. Marshall, M.; Taçon, P.S.C. Past and present, traditional and scientific: The conservation and management of rock art sites in Australia. In Open-Air Rock-Art Conservation and Management: State of the Art and Future Perspectives; Darvill, T., Fernandes, A.P.B., Eds.; Routledge: London, UK, 2014; pp. 214-228.

33. Taçon, P.S.C.; Marshall, M. Conservation or Crisis? The Future of Rock Art Management in Australia. In $A$ Monograph of Rock Art Research and Protection; Zhang, Y., Ed.; China Tibetology Publishing House: Beijing, China, 2014; pp. 119-141.

34. Sayer, F. Understanding well-being: A mechanism for measuring the impact of heritage practice on well-being. In The Oxford Handbook of Public Heritage Theory and Practice; Labrador, A.M., Silberman, N.A., Eds.; Oxford University Press: Oxford, UK, 2018.

35. Darvill, T. Value systems in archaeology. In Managing Archaeology; Cooper, M.A., Firth, A., Carman, J., Wheatley, D., Eds.; Routledge: London, UK, 1995; pp. 40-50.

36. Holtorf, C. From Stonehenge to Las Vegas: Archaeology as Popular Culture; Altamira Press: Oxford, UK, 2005.

37. Renfrew, C. Figuring it Out: What are We? Where Do we Come from? Thames and Hudson: London, UK, 2006.

38. The EuroQol Group. EuroQol: A new facility for the measurement of health-related quality of life. Health Policy 1990, 16, 199-208. [CrossRef]

39. Watson, D.; Clark, L.A.; Tellegen, A. Development and validation of brief measures of positive and negative affect: The PANAS scale. J. Pers. Soc. Psychol. 1988, 54, 1063-1070. [CrossRef]

40. Ferraro, E.; Barletti, J.P.S. Place wellbeing: Anthropological perspectives on wellbeing and place. Anthropol. Action 2016, 23, 1-5. [CrossRef]

41. Zarandona, J.A.G. The destruction of heritage: Rock art in the Burrup Peninsula. Int. J. Hum. 2011, 9, 325-342.

42. Cunliffe, E.; Curini, L. ISIS and heritage destruction: A sentiment analysis. Antiquity 2018, 92, $1094-1111$. [CrossRef]

43. Isakhan, B.; Meskell, L. UNESCO's project to "Revive the spirit pf Mosul": Iraqi and Syrian opinion on heritage after the Islamic State. Int. J. Herit. Stud. 2019. [CrossRef]

44. Shahab, S.; Isakhan, B. The ritualization of heritage destruction under Islamic State. J. Soc. Archaeol. 2018, 18, 212-233. [CrossRef]

45. Zarandina, J.A.G.; Albarrán-Torres, C.; Isakhan, B. Digitally mediated iconoclasm: The Islamic State and the war on cultural heritage. Int. J. Herit. Stud. 2018, 24, 649-671. [CrossRef]

46. Nobbs, C. Australia's Assault on Norfolk Island, 2015-2016: Despatches from the Front Line; Chris Nobbs: Burnt Pine, Australia, 2017. 
47. Samuels, K.L. Deliberate heritage: Difference and disagreement after Charlottesville. Public Hist. 2019, 41, 121-132. [CrossRef]

48. Lopez, G. The Battle over Confederate Statues, Explained. Vox. August 2017. Available online: https://www. vox.com/identities/2017/8/16/16151252/confederate-statues-white-supremacists (accessed on 25 September 2017).

49. Grant, S. It is a "damaging myth" that Captain Cook discovered Australia. ABC News. 23 August 2017. Available online: http://www.abc.net.au/mews/2017-08-23/stan-grant:-damaging-myth-captain-cookdiscovered-australia/8833536 (accessed on 25 September 2017).

50. Barnabas, S. Engagement with colonial and apartheid narratives in contemporary South Africa: A monumental debate. J. Lit. Stud. 2016, 32, 109-128. [CrossRef]

51. McLay, E.; Bannister, K.; Joe, L.; Thom, B.; Nicholas, G. A'lhut tut et Sul'hweentst [Respecting the ancestors]: Understanding Hul'qumi'num heritage laws and concerns for the protection of archaeological heritage. In First Nations Cultural Heritage and Law: Case Studies, Voices and Perspectives; Bell, C., Napoleon, V., Eds.; UBC Press: Vancouver, BC, Canada, 2008; pp. 158-202.

52. Auclair, E.; Fairclough, G. Living between past and future: an introduction to heritage and cultural sustainability. In Theory and Practice in Heritage and Sustainability: Between Past and Future; Auclair, E., Fairclough, G., Eds.; Routledge: New York, NY, USA, 2015; pp. 1-22.

53. Barthel-Bouchier, D. Cultural Heritage and the Challenge of Sustainability; Routledge: New York, NY, USA, 2016.

54. Baker, S.; Collins, J. Popular music heritage, community archives and the challenge of sustainability. Int. J. Cult. Stud. 2017, 20, 476-491. [CrossRef]

55. Willman, C. Musicians Freak Out as They Belatedly Learn Myspace Lost 50 Million Songs. Variety. 18 March 2019. Available online: https://variety.com/2019/music/news/myspace-music-data-loss-50-million-songs1203165649/ (accessed on 29 March 2019).

56. Gao, Q. Social values and rock art tourism: An ethnographic study of the Huashan Rock Art Area (China). Conserv. Manag. Archaeol. Sites 2017, 19, 82-95. [CrossRef]

57. Salazar, N.B.; Zhu, Y. Heritage and tourism. In Global Heritage: A Reader; Meskell, L., Ed.; Wiley Blackwell: Chichester, UK, 2015; pp. 240-258.

58. Harvey, D.; Perry, J. (Eds.) The Future of Heritage as Climates Change: Loss, Adaptation and Creativity; Routledge: Milton Park, UK, 2015.

59. Högberg, A.; Holtorf, C. Heritage futures and the future of heritage. In Counterpoint: Essays in Archaeology and Heritage Studies in Honour of Professor Kristian Kristiansen; Bergerbrant, S., Sabatini, S., Eds.; Archaeopress: Oxford, UK, 2013; pp. 739-746.

60. Högberg, A.; Holtorf, C.; May, S.; Wollentz, G. No future in archaeological heritage management? World Archaeol. 2018, 49, 639-647. [CrossRef]

61. Wise, P. Minor heritage matters: understanding well-being in the Gold Coast Tweed region. Presented at the "New and Emerging Challenges to Heritage and Well-Being" conference, Griffith University, Gold Coast, QLD, Australia, 23 November 2016.

62. Katriel, T. "Our future is where our past is": Studying heritage museums as ideological and performative arenas. Commun. Monogr. 1993, 60, 69-75. [CrossRef]

63. Meskell, L. Introduction: Globalizing heritage. In Global Heritage: A Reader; Meskell, L., Ed.; Wiley Blackwell: Chichester, UK, 2015; pp. 1-21.

64. Stanco, F.; Battiato, S.; Gallo, G. Digital Imaging for Cultural Heritage Preservation; CRC Press Inc.: Boca Raton, FL, USA, 2011.

65. Beer, D.; Burrows, R. Popular culture, digital archives and the new social life of data. Theory Cult. Soc. 2013, 4, 47-71. [CrossRef]

66. Bolick, C.M. Digital archives: Democratizing the doing of history. Int. J. Soc. Educ. 2006, 21, 122-134.

67. Featherstone, M. Archiving cultures. Brit. J. Sociol. 2000, 51, 161-184. [CrossRef]

68. Pieraccini, M.; Guidi, G.; Atzeni, C. 3D digitizing of cultural heritage. J. Cult. Herit. 2001, 2, 63-70. [CrossRef]

69. Silberman, N.A. Beyond theme parks and digitized data: What can cultural heritage technologies contribute to the public understanding of the past? In Proceedings of the VAST: 5th International Symposium on Virtual Reality, Archaeology and Intelligent Cultural Heritage, Brussels and Oudenaarde, Belgium, 7-10 November 2004. 
70. Lerma, J.L.; Navarro, S.; Cabrelles, M.; Villaverde, V. Terrestrial laser scanning and close range photogrammetry for 3D archaeological documentation: The Upper Palaeolithic Cave of Parpalló as a case study. J. Archaeol. Sci. 2010, 37, 499-507. [CrossRef]

71. Barnett, T.; Chalmers, A.; Díaz-Andreu, M.; Ellis, G.; Longhurst, P.; Sharpe, K.; Trinks, I. 3D laser scanning for recording and monitoring rock art erosion. Int. Newsl. Rock Art 2005, 41, 24-29.

72. Chandler, J.H.; Bryan, P.; Fryer, J.G. The development and application of a simple methodology for recording rock art using consumer-grade digital cameras. Photogramm. Rec. 2007, 22, 10-21. [CrossRef]

73. El-Hakim, S.F.; Fryer, J.; Picard, M. Modeling and visualization of Aboriginal rock art in the Baiame Cave. Int. Arch. Photogramm. Remote Sens. 2004, 35, 990-995.

74. Di Maida, G. 3D in the cave: Hey young deer, why the long face (and no tail)? Rock Art Res. 2016, 33, $209-281$.

75. Domingo, I.; Villaverde, V.; López-Montalvo, E.; Lerma, J.L.; Cabrelles, M. Latest developments in rock art recording: Towards an integral documentation of Levantine rock art sites combining 2D and 3D recording techniques. J. Archaeol. Sci. 2013, 40, 1879-1889. [CrossRef]

76. Fraile, F.J.L.; García, L.M.G.; Klink, A.C. Documentation and use of DStretch for two New Sites with Post-Palaeolithic Rock Art in Sierra Morena, Spain. Rock Art Res. 2016, 33, 127-142.

77. González-Aguilera, D.; Muñoz-Nieto, A.; Gómez-Lahoz, J.; Herrero-Pascual, J.; Gutierrez-Alonso, G. 3D digital surveying and modelling of cave geometry: Application to Paleolithic rock art. Sensors 2009, 9, 1108-1127. [CrossRef]

78. Jalandoni, A.; Domingo Sanz, I.; Taçon, P.S.C. Testing the value of low-cost Structure-from-Motion (SfM) photogrammetry for metric and visual analysis of rock art. J. Archaeol. Sci. Rep. 2018, 17, 605-616. [CrossRef]

79. Haubtm, R.; Taçon, P.S.C. A collaborative, ontological and information visualization model approach in a centralized rock art heritage platform. J. Archaeol. Sci. Rep. 2016, 10, 837-846. [CrossRef]

80. Myers, D.; Dalgity, A.; Avramides, I. The arches heritage inventory and management system: A platform for the heritage field. J. Cult. Herit. Manag. Sustain. Dev. 2016, 6, 213-224. [CrossRef]

81. Vincent, M.L.; Flores Gutierrez, M.; Coughenour, C.; Lopez-Menchero Bendicho, V.M.; Remondino, F.; Fritsch, D. Crowd-sourcing the 3D digital reconstructions of lost cultural heritage. Dig. Herit. 2015, 1, 171-172. [CrossRef]

82. Turner, M.; Dowsland, S.; Mazel, A.; Giesen, M. Rock art CARE: A cross-platform mobile application for crowdsourcing heritage conservation data for the safeguarding of open-air rock art. J. Cult. Herit. Manag. Sustain. Dev. 2018, 8, 420-433. [CrossRef]

83. Baker, F. Rock-art and digital difference. In Proceedings of the 19th International Conference on Cultural Heritage and New Technologies 2014, Vienna, Austria, 2014; Börner, W., Uhlirz, S., Eds.; Museen der Stadt Wien: Vienna, Austria, 2014; pp. 1-6.

84. Galeazzi, F. 3-D virtual replicas and simulations of the past. "Real" or "fake" representations? Curr. Anthropol. 2018, 59, 268-286. [CrossRef]

85. Stobiecka, M. Digital escapism: How objects become deprived of matter? J. Contemp. Archaeol. 2018, 5, 194-212. [CrossRef]

86. Thomas, J. Archaeology and Modernity; Routledge: London, UK, 2004.

87. Taçon, P.S.C. The Creativity Centre: Where art meets science. In Between Indigenous Australia and Europe: John Marwurndjul; Volkenandt, C., Kaufmann, C., Eds.; Aboriginal Studies Press/Reimer: Canberra, Australia; Berlin, Germany, 2009; pp. 211-216.

88. Colwell, C.; Joy, C. Communities and ethics in the heritage debates. In Global Heritage: A Reader; Meskell, L., Ed.; Wiley Blackwell: Chichester, UK, 2015; pp. 112-130.

89. Ndoro, W.; Wijesuriya, G. Heritage management and conservation: From colonization to globalization. In Global Heritage: A Reader; Meskell, L., Ed.; Wiley Blackwell: Chichester, UK, 2015; pp. 131-149.

90. National Trust. Places that Make Us-Research Report; National Trust: Swindon, UK, 2017.

91. Smith, C.; Ralph, J.; Notre Dame: How a Rebuilt Cathedral Could be just as Wonderful. Notre Dame: How a Rebuilt Cathedral Could be just as Wonderful. The Conversation. 16 April 2019. Available online: http://theconversation.com/notre-dame-how-a-rebuilt-cathedral-could-be-just-as-wonderful-115551 (accessed on 17 April 2019).

92. DeSilvey, C. Curated Decay: Heritage Beyond Saving; University of Minnesota Press: Minneapolis, MN, USA, 2017. 
93. Harrison, R. Forgetting to remember, remembering to forget: Late modern heritage practices, sustainability and the 'crisis' of the accumulation of the past. Int. J. Herit. Stud. 2011, 19, 579-595. [CrossRef]

94. Poulios, I. The Past in the Present: A Living Heritage Approach-Meteora, Greece; Ubiquity Press: London, UK, 2014.

(C) 2019 by the authors. Licensee MDPI, Basel, Switzerland. This article is an open access article distributed under the terms and conditions of the Creative Commons Attribution (CC BY) license (http://creativecommons.org/licenses/by/4.0/). 